STUDY OF THREATENED AND ENDANGERED

PLANTS IN THE WELLS S.E. AREA, NEVADA

$$
\text { YA-512-RFP9-62 }
$$

TECHNICAL PROPOSAL

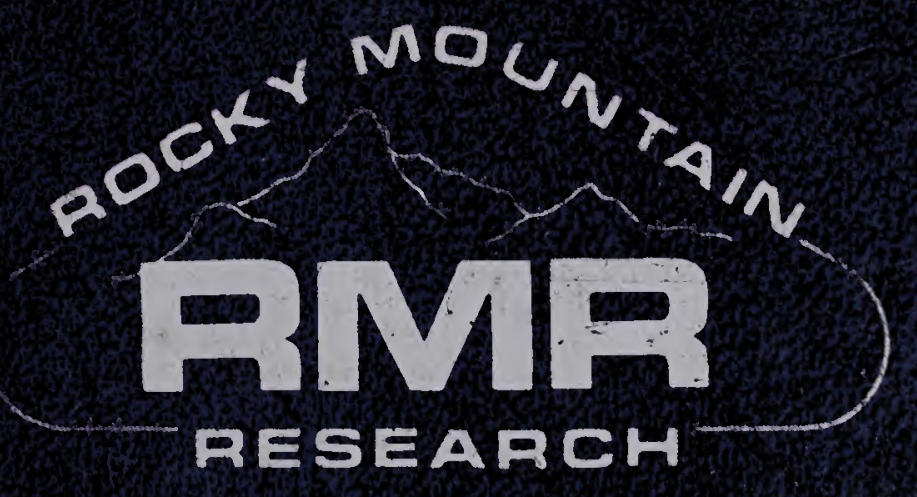




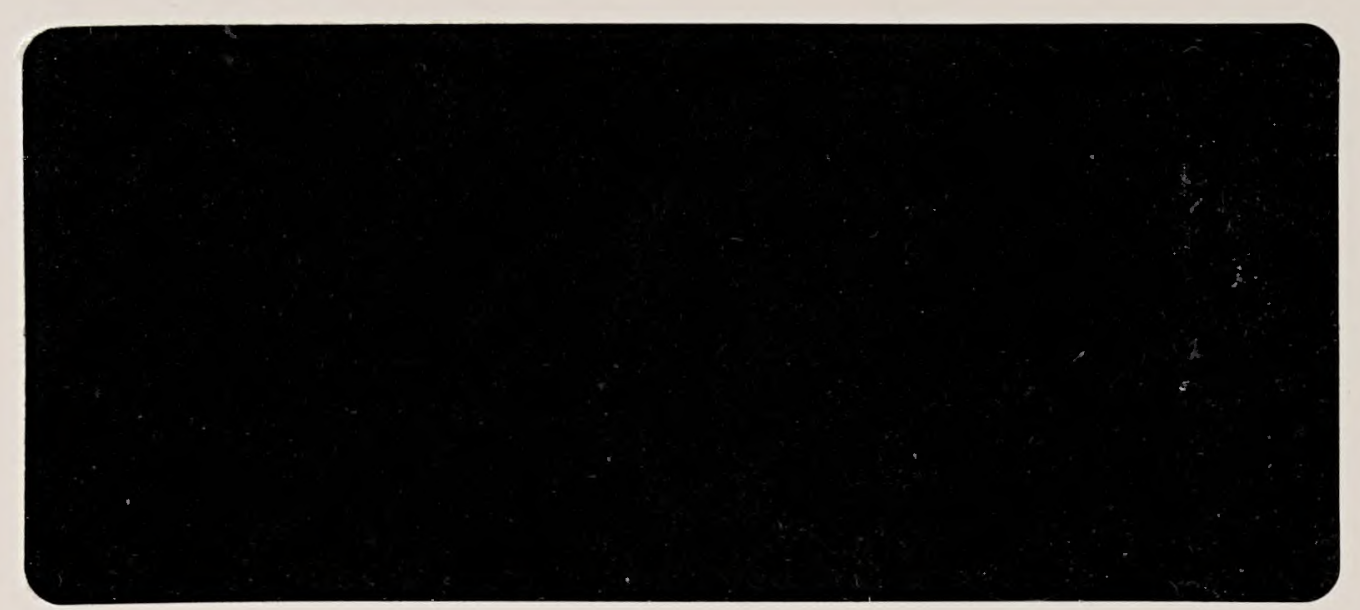

242 NORTH UNIVERSITY AVE. PROVO, UTAH B46OT

BUS. OFFICE (8OT) 374-6268 RESEARCH OFFICE (801) 374-6269 RMR/DEA of HBS Research 
TECHNICAL PROPOSAL 



\title{
STUDY OF THREATENED AND ENDANGERED PLANTS
}

\author{
Prepared for: \\ Bureau of Land Management \\ Denver Federal Center Bldg 50 \\ Denver, Colorado 80225
}

\author{
Prepared by: \\ Inter-Mountain Research, Incorporated \\ 242 North University Avenue \\ Provo, Utah 84601
}

March 19, 1979 

Introduction . . . . . . . . . . . . . . . . . . 1 Objectives.......................... . . 1 Approach to Field Survey . . . . . . ... . . . . . . 1 Method of Conducting Field Search . . . . . . . . . . . 3 Tasks and Identifying Numbers . . . . . . . . . . . 7 Time and Man Hour Matrix .. . . . . . . . . . . 8 Deliverables . . . . . . . . . . . . . . . 9 Personnel ........................ 11 



\section{INTRODUCTION}

This proposal presents the stens that will be taken to carry out a field search for the threatened and endangered plants that occur in the Te11s E.S. Area of Nevada which comprizes some 4,978,000 acres. This study is to be carried out on the public lands of this area, excluding National Forest lands, and on such private lands as are desirable and accessible.

The plants that will be of special concern in this study are those listed for Elko County in the RFP Attachment 2. The known collection sites of these species are plotted in the "Map Book, Endangered and Threatened Plants of Nevada" by Ann Pinzl. Such other plants as are found to be rare enough for designation as threatened or endangered will be sought.

\section{OBJECTIVES}

The purpose of this survey is to inventory the rare plants of the Wells study area and to learn as much as possible within the limits of this contract about phenology, habitat requirements, distribution, factors that threaten their growth, survival, and mean of aiding the latter.

\section{APPROACH TO FIELD SURVEY}

A field survey of any sizeable area is time consuming and costly. Therefore, such surveys must be well planned so as to achieve the objective as completely as possible with a minimum effort. At best, a survey achieves 

only a sampling of a large area; hence good sampling techniques must be applied. However, in this project, one should not base the time spent sampling any plant type on its proportionate area because rare plants are not uniformly distributed throughout al1 plant types.

Rare plants suffer from a competitive disadvantage in relation to other plants. Otherwise, they would not be rare. Since they are poor competitors, they generally take "second best" in the choice of habitats. One can expect to find rare plants on rocky ridges, rocky outcrops or breaks, in high elevations, and lowland valleys (especially in heavy soil, saline soils, and sand).

Rare plants are mostly perennials, never vigorous pioneering annuals. Therefore, a stable environment is favorable to their occurrence. They rarely occur on disturbed soils and disturbing activities are inimical to their survival. The majority of the thirteen rare plants listed from Elko County are perennials.

The principal exceptions to the above generalizations are taxa of recent origin, plants dependent on a particular geological stratum or soil of limited occurrence, or plants that have been crowded into a limited area by destruction or modification of a once extensive habitat.

Based on the foregoing assessment of the facts, it follows that the 2 time and effort spent surveying each type of habitat should be influenced by the liklihood of finding rare plants there as well as by its proportional area. Ideally, no type of habitat can be ignored. One cannot predict with complete accuracy what is to be found in nature while sitting at a desk. 

METHOD OF CONDUCTING FIELD SEARCH

Before undertaking the actual field work, a certain amount of information will be compiled about each rare plant listed as occurring in the study area. As many of the following data as can be learned from the available literature and an examination of specimens in the Brigham Young University Herbarium will be assembled. This information should save valuable field time:

1. Known localities where the plant has been collected or observed. This is largely available in the "Map Book: Endangered and Threatened Plants of Nevada" by Ann Pinzl.

2. Ecology; including soil type, geology, elevation, slope, and associated plants.

3. Dates of collections, phenology.

The start of field work will be determined by the date of awarding the contract, but ideally, it should be begun not later than May 14 . The field search will be carried out for the succeeding three weeks, (two weeks in late June and one week in August). The search will be made on foot by a field team of two individuals, Dr. Robert H. Foster and Dan A. Foster. In addition, Dr. Bertrand F. Harrison, Principal Investigator, will spend one week in the field with the survey team and Dr. Stanley L. Velsh, Curator of the BYU Herbarium, will spend three days in the field near the beginning of the field work and will spend two days identifying the specimens at such times as needed.

The field party will live in the field as near the search area as feasible. Four days each week will be spent in field work with the fifth spent in drying plants, writing up field notes and preparing for the next 

field operation. Initially, the field work will consist of searching the specific locales where rare plants have been collected previously, beginning with the lower elevations and progressing to the higher elevations. When such a plant is found, the various habitat characteritistics associated with the species will be recorded:

1. Elevation

2. Exposure

3. Slope

4. Soil type

5. Specific location

6. Distance and bearing from a prominent geological feature

7. Date

8 Associated plant species (especially dominant species)

9. Collector

If the size and vigor of the population is adequate, then specimens sufficient for two herbarium sheets will be collected. If the population is critically small, then collection will be delayed until directions can be derived from the COAR or until additional specimens can be found. If a population is sufficiently large, specimens for a third herbarium sheet will be collected and deposited in the BYU Herbarium. Photographs will be taken as soon as plants in satisfactory condition are located.

A search will be made for each of the plants listed below, which have been collected in the Wells study area. ${ }^{1}$ However, the search will not be limited to the rare plants listed:

(T) Astragalus lentiginosus Doug1 var latus (Jones) Jones

(T) Cryptantha interrupta (Greene) Payson

${ }^{1}$ Ann Pinz1, "Map Book: Endangered and Threatened Plants of Nevada. 

(E) Eriogonum argophyllum Reveal

(T) Sclerocactus pubispinus (Engelm) L. Benson

Two other species are found just outside of the study area and most likely occur within the boundaries of the study area:

(E) Antennaria arcuata

(T) Thelypodium sagittatum var ovalifolium

An additional six species are reported as occurring from the county, but are presently known only from National Forest lands.

While it is likely that there are more rare plants in the southern part of Nevada than in the northern portion, the limited number of rare plants reported from the Wells area may be due in part to a lack of adequate collecting.

Timing of the visits to each area is very important. Most plants must be in full flower for accurate identification. In addition, some plants such as species of Cruciferae and Astragalus should also be seen with mature fruit. Hence, a second or third visit will need to be made to some collection sites.

Using the information gained in the initial field work as a guide, the search for threatened and endangered plants will be extended to similar habitats within the study area. The location of similar plant communities may be found by a study of aerial photos, vegetation type maps, or consultation with Bureau personnel. The study of these additional communities will be limited by the time constraints of the contract.

If time permits, it may be desirable to examine some sites that are adjacent to the study area to see if some of the species should be deleted from the list of rare plants. For example, Blepharidachne kingii has been 

regarded as very rare in Utah but it has been found locally abundant south of Wendover (especially on the Nevada side of the line).

During the course of the field studies, observations will be made and recorded so as to aid in the preparation of a final report based on sound judgment regarding the critical habitat, endemic centers, causes of decline or increase. Recommendations as to whether a species should be maintained in the Smithsonian Proposed List, deleted from the List, or added to the List, as well as for a species preservation should be based on observations made in the field as well as the number and distribution of plants found. Plants collected will be pressed as soon after collection as is feasible and dried quickly. Plants will be taken to Provo, generally weekly, and checked with specimens in the Brigham Young University Herbarium whenever the identification warrants verification. The plants will be mounted by Mrs. Kaye Thorne, Assistant Curator of the BYU Herbarium.

It is understood that it will be the responsibility of the contractor to provide all equipment and supplied required for completing this project except for the maps specified in the RFP, page 33, J-8. This includes such items as trucks, camping equipment, plant presses, picks, plastic bags, drying equipment, altimeter, magnifiers, field books, and photographic equipment. It is further understood that the contractor is responsible for obtaining permits for entering on private lands and must abide by all restrictions for using public lands.

The field search will be carried forward in 1980 essentially as outlined in the foregoing proposal. However, it is anticipated that experience on the ground will provide guidance for some improvements and perhaps some increases in our efficiencies. It is hoped that counsel from members of the Bureau of Land Management will aid us in this same manner. 

TASKS AND IDENTIFYING NUMBERS

1.1 Review of 1iterature

1.2 Planning field survey

2.0 Field search including collecting and pressing plants, making field notes, taking photos

2.1 Plant identification

2.2 Mounting plants

2.3 Writing reports

2.4 Drafting

2.5 Typing 



\begin{tabular}{|c|c|c|c|c|c|c|c|c|}
\hline \multirow[b]{2}{*}{ 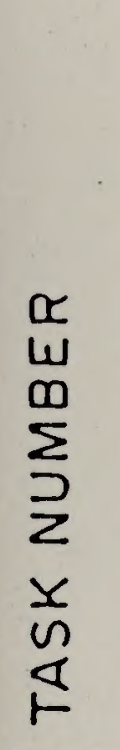 } & \multicolumn{7}{|c|}{$\begin{array}{l}\text { AVERAGE DAYS PER } \\
\text { TASK BY INDIVIOUALS }\end{array}$} & \\
\hline & $\begin{array}{l}2 \\
0 \\
0 \\
0 \\
0 \\
0 \\
7 \\
1 \\
0 \\
0\end{array}$ & 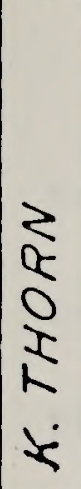 & 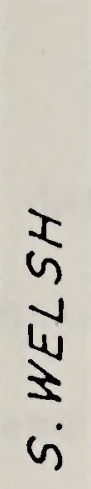 & $\begin{array}{l}G \\
0 \\
\vdots \\
0 \\
0 \\
0 \\
0\end{array}$ & 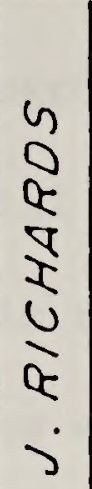 & $\mid \begin{array}{l}\frac{2}{4} \\
4 \\
2 \\
0 \\
0 \\
0 \\
0\end{array}$ & $\begin{array}{l}a \\
w \\
k \\
n \\
0 \\
4 \\
0 \\
0\end{array}$ & \\
\hline 1.0 & 1 & & & & & & & 1 \\
\hline 1.1 & 2 & & & & & & & 2 \\
\hline 2.0 & 3 & & 3 & & & & 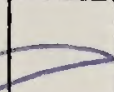 & 6 \\
\hline 2.1 & & & 2 & & & 60 & 60 & 122 \\
\hline 2.2 & & 2 & & & & & & 2 \\
\hline 2.3 & 2 & & & & & & & 2 \\
\hline 2.4 & & & & 2 & & 5 & & 7 \\
\hline 2.5 & & & & & 2 & & & 2 \\
\hline & 8 & 2 & 5 & 2 & 2 & 65 & 60 & 144 \\
\hline
\end{tabular}

TIME SPAN DEVOTED TO EACH TASK

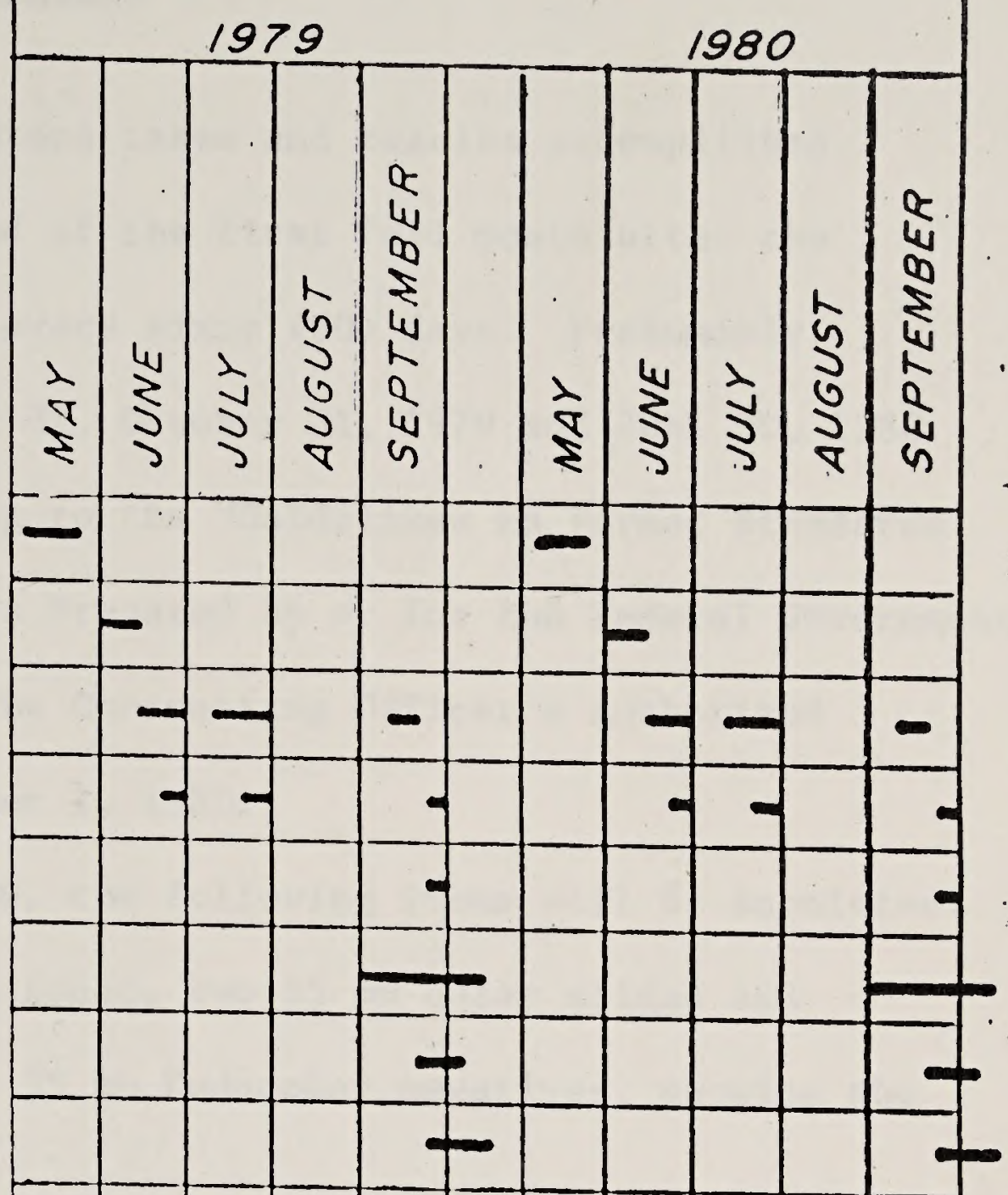





\section{DELIVERABLES}

A progress report giving the steps taken and results accomplished to date will be submitted at the end of the first full month after the contract is awarded and thereafter every sixty (60) days. Presumably these dates will be June 29, August 31, October 31, 1979 and June 30, 1980.

A Draft Final Report conforming to the "Guidelines to Format Standards for Scientific and Technical Reports Prepared by or for the Federal Government" will be prepared and submitted to the Contracting Officer's Authorized Representative on or before September 1, 1980.

On or before September 30, 1980, the following items will be submitted:

1. For each $\mathrm{T} / \mathrm{E}$ plant species found, two $35 \mathrm{~mm}$ color slides and two $5 \times 7$ " color prints with $35 \mathrm{~mm}$ Kodacolor negatives, showing the following:

(a) Close-up of the individual plant species

(b) A typical growing plant and its surroundings

(c) Close-up showing details of taxonomic features

2. Two herbarium mounts on standard size rag content herbarium paper, provided with a plastic cover or coated to preserve the specimen in a professional manner. No specimens of taxa judged to be too scarce by this contractor and approved by the COAR will be collected. Succulents may or may not be collected. All mounts will be provided with a label giving the technical name, common names, and complete collection data as specified under No. 2, Section F.

3. The location and distribution of each species, subspecies, or variety plotted on a $1 " /$ mile planimetric map. 

4. After responding to comments of the reviewing officers and receiving approval of the Bureau, a Final Report will be prepared and submitted in five (5) copies plus one (1) reproducible master. This report will be submitted on or before September 30, 1980 . The final report will include, as a minimum, the following:

(a) Review of literature describing the threatened and endangered plants, their phenology, and their habitat requirements.

(b) An opinion on such factors as critical habitat, endemic centers and reasons for decline or increase.

(c) Evidence of threat or damage through the use of chemical or livestock grazing.

(d) An assessment of five specified land treatments in relation to jeopardizing the continued existence of the species, either directly or indirectly through midification of the habitat.

(e) A summary evaluation of this study giving negative as well as postive aspects and recommendations for future studies.

5. Recommendations for each species as to whether it should be retained or deleted from the Lest of $\mathrm{T} / \mathrm{E}$ plants or if new ones should be added.

6. At the option of the Bureau, the Contractor may be required to supply copies of certain items such as field notes and write-up sheets. 



\section{PERSONNEL}

Dr. Bertrand F. Harrison, Principal Investigator, Professor Emeritus, Botany and Range Science. Chairman of Botany and Range Science Department, Brigham Young University (23 years). Curator of BYU Herbarium (1931-1960); has conducted many field ecology trips; has personally collected over 10,000 plants throughout Utah, as well as many in Nevada, Wyoming, and Arizona. Specialist in taxonomy and ecology of grasses.

Dr. Stanley L. Welsh, Consultant Professor of Botany and Range Science, Curator of BYU Herbarium; author of Flora of Alaska, Common Plants of Utah, and many technical papers. Specialist in Threatened and Endangered plants with extensive field experience.

Dr. Robert H. Foster, Team Leader, Ph.D in Botany (Biogeography) BYU, 1968. Professor Emeritus, Earth Sciences University of Georgia. Extensive field experience including eight month survey of threatened and endangered plant species, Utah.

Dan A. Foster, Field Assistant, completing his junior year at BYU with a major in Botany and Range Science; considerable field experience with his father. 



\section{VITAE}

Name: Bertrand F. Harrison

Born: February 20, 1908, Springville, Utah

Address: 655 North 1130 East; Provo, Utah 84601

Married: Lorna Jensen September 17, 1931

Title: Professor Emeritus, Botany and Range Science

Education:

Institution and Location

Brigham Young University Provo, Utah

Brigham Young University Provo, Utah

University of Chicago

Chicago, Illinois

$\begin{array}{lccc}\text { Degree } & \begin{array}{c}\text { Year } \\ \text { Conferred }\end{array} & & \begin{array}{c}\text { Scientific } \\ \text { Field }\end{array} \\ \text { B.S. } & 1930 & & \text { Botany } \\ \text { M.S. } & 1931 & & \text { Botany } \\ \text { PhD } & 1937 & & \text { Botany }\end{array}$

Honors: Phi Kappa Phi

Karl G. Maeser Distinguished Teaching Award 1966

Brigham Young University Alumni Association Distinguished Service Award 1976

Listed in American Men of Science

Listed in Who's Who in America

Professional Affiliations:

American Association of Plant Physiologists

Botanical Society of America

Utah Academy of Sciences, Arts and Letters, Fellow and Past President

The Society of the Sigma Xi, Past President of B.Y.U. Chapter 

Research Interests:

Stress physiology of plants

Plant ecology

Ecology and taxonomy of grasses

Professional Experience:

Ranger Naturalist, Yellowstone National Park 1931

Instructor in Botany, B.Y.U. 1931-35

Assistant Professor of Botany, B.Y.U. 1935-37

Associate Professor of Botany, B.Y.U. 1937-38

Professor of Botany, B.Y.U. 1938-74

Professor Emeritus Botany \& Range Science, B.Y.U. 1974--

Chairman Botany Department 1935-58; 1961-64

Research Associate, American Smelting \& Refining Co. Agricultural Research Laboratory 1943, 1944

Member of Utah Department of Transportation Environmental Council 1973--present; chairman of Council 1975-77

Consultant Inter-Mountain Research Corp.

Vegetation and Range section of Land Use Plan for Crow Indian Reservation, Montana 1977

Vegetation Survey Leucite Hills Project, Wyoming 1977

Publications :

Harrison, Bertrand F. 1932. The rise and development of the megagametophyte in Fritillaria pudica and Fritillaria atropurpurea. Proc. Utah Acad. of Science, 9:9-20.

Harrison, Bertrand F. 1937. Histological responses of Iresine lindenii to indoleacetic acid. Botanical Gazette, $99: 301-338$.

Harrison, Bertrand F. 1939. An annotated list of Utah grasses. Proc. Utah Academy Sciences, Arts, and Letters, 16:23-35. 

Nisson, A.W., and B.F. Harrison. 1940. The rise and development of the megagametophyte of Yucca angustissima Englm. Proc. Utah Academy of Sciences, Arts, and Letters, 17:73-83.

Cottam, W.P., A.O. Garrett, and B.F. Harrison. 1940. New and extended ranges for Utah plants. Bulletin of the Univ. of Utah, 30:1-11.

Harrison, Bertrand F., Moyer D. Thomas and Geo. R. Hill. 1944. Radio-autographs showing the distribution of sulphur in wheat. Plant Physiol., 19:245-257.

Harrison, Bertrand F. 1955. Grass -- "Chief Nourisher in Life's Feast." (Presidential Address). Proc. of Utah Academy of Sciences, Arts, and Letters. 31:13-23.

Harrison, Bertrand F. 1957. A Botanical Garden at Brigham Young University. Proc. of Utah Academy of Sciences, Arts, and Letters. 34:45-49.

Harrison, Bertrand F. and Richard F. Nelson. 1957. Preliminary investigation of the role of selenium in Stanleya pinnata. Proc. of Utah Academy of Sciences, Arts, and Letters. $34: 159$.

Harrison, Bertrand F., and others. 1960. Laboratory Botany. Seventh Edition, 175 pp. Wm. C. Brown Co., Inc. Dubuque, Iowa.

Christensen, Earl M., and B.F. Harrison. 1961. Ecological study area of lily lake in the Uinta Mountains, Utah. Proc. Utah Acaddemy of Sciences, Arts, and Letters.

Harrison, Bertrand F., Stanley Welsh, and Glen Moore. 1964. Plants of Arches National Monument. Brigham Young Univ. Science Bulletin, Biol. Series, 5:1-24.

Research Projects Completed in Connection with Grants from UtahIdaho Sugar Co. and Kennecott Copper Co.:

1. The protective action of various pelleting materials against the damping-off fungi Phoma beta, Pythium debaryanum and Rhigoctonia solani in germinating sugar beet seeds.

2. The Effect of seed and row spacing on yield of sugar beets. 

3. The Effects of various fertilizer treatments and spacing on yield and sugar content of sugar beets.

4. The influence of varying rates of application of copper sulphate and mill tailings on copper uptake and yield of sugar beets. This paper presented to American Society of Plant Physiologists, Western Section. 



\section{CURRICULUM VITAE}

Name: Stanley L. Welsh

Birthdate: 7 September 1928

Birthplace: Rockport, Summit Co., Utah, USA

Present Nationality: USA

Title: Professor of Botany and Range Science

Education:

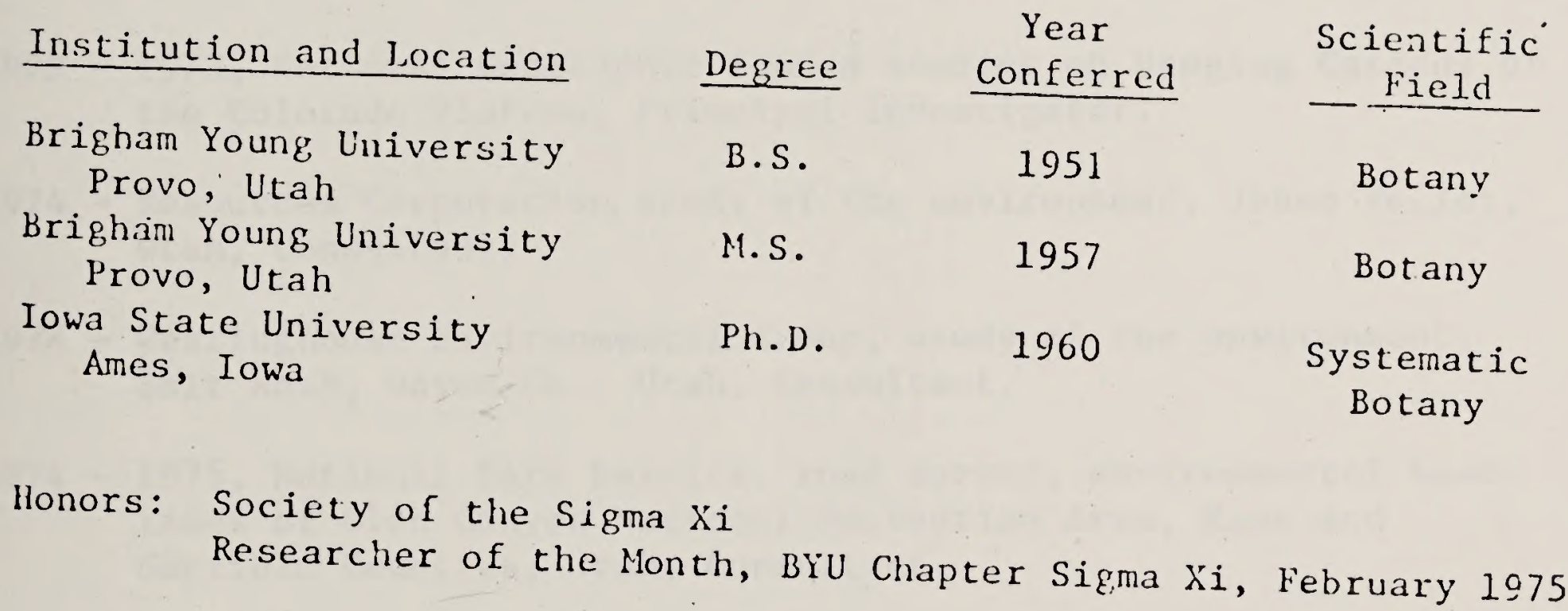

Najor Research Interest: Taxonomy of Utah plants, North American Astragilus, and arctic Anerican plants 
Research and Professional Experience:

1960 - present, Brigham Young University, Professor of Botany and Range Science.

1962 - 1965, Wetherill Mesa Archeological Project, Mesa Verde National Park, Colorado, Consultant.

1964 - National Park Service, Natural Bridges National Monument, Utah, Consultant on master plan.

1965 - 1974, Alaska Flora Project, Iowa State University, Ames, Iowa, . Principal Investigator.

1965 - 1970, Research Advisory Board, Arches--Canyonlands National Park, Chairman.

1971 - 1974, Navajo-Kaiparowits Environmental Baseline Studies, Kane Co., Utah, and Coconino Co, Arizona, Project Director.

1972 - 1973, National Geographic funded studies on Hanging Gardens of the Colorado Plateau, Frincipal Investigator.

1974 - Resources Corporation, study of the environment, Johns Valley, Utah, Consultant.

1974 - Westinghouse Environmental Group, study of the environment, Salt Wash, Wayne Co., Utah, Consultant.

1974. - 1975, National Park Service, road survey, environmental baselines of Glen Canyon National Recreation Area, Kane and Garfield Counties, Utah, Consultant.

1976 - Bureau of Land Management, endangered and threatened plant species in Richfield and Cedar City Districts, Utah, Principal Investigator.

1976 - Rolling, Brown, and Cunne11, Inc., existing environmental conditions of Mapleton Center Street, Utah Co., Utah, Consultant.

1977 - United States Geological Survey, threatened and endangered species of the Southern and Central Coal lands, Utah, Project Dfrector.

1977 - Consolidation Coal Company, survey of endangered and threatened plant species, Kaiparowits Plateau and Collet Canyon vicinity, Consultant. 

1977 - Buttes Gas and O1I Co., survey of endangered and threatened plant species, Ten Mile Area, Grand Co., Utah, Consultant.

1977 - Mountain States Resource Corporation, endangered and threatened plant species survey on coal properties, Consultant.

1977 - United States Forest Service, survey of endangered and threatened plant species along the Utah Power and Light transmission line in Spanish Fork Canyon, Utah, Consultant.

1977 - Cordillera Corporation, survey of endangered and threatened plant species, Consultant.

1977 - Vaughn Hansen Associates, report of preliminary studies of endangered and threatened plant species along Utah Power and Light transmission lines, Consultant.

1977 -. Dames and Moore Inc., report of preliminary studies on endangered and threatened plant species, Lynndyl, Horse Bench, Hanksville, Desert North, and Beckwith areas, Consultant.

1977 - Water Conservancy District, Moab, endangered and threatened plant species, Mill Creek, Utah, Consultant.

1978 - Buttes Gas and Oil, survey of endangered and threatened plant species, Ten Mile Point Area, Grand Co., Utah, Consultant.

1978 - Vaughn Hansen Assoclates, preliminary studies of plant sites, access roads, railroad, pipelines, and transaission corridors, Utah Power and Light Company, Consultant.

1978 - Utah Power and Light Company, coal exploration area, East Mountain, Emery Co., Utah, Consultant.

1978 - Bannock--Oneida threatened and endangered plants, Bureau of Land Management, Burley District, Idaho; Principal investigator.

1978 - Ford, Bacon, and Davis, biotic evaluation of inactive Uranium Mill Tailings, Oregon, Idaho, Wyoming, Colorado, Utah, New Mexico, and Texas, Princlpal investigator.

1978 - Deep Creek Mountains, Utah Bureau of Land Management; Principal investigator.

1978 - Fish Lake National Forest, endangered and threatened plants, Rangelands Resources International Inc., Consultant.

1978 - Survey of endangered and threatened plants, Intermountain Power Project, plant site, railroad spur, water pipline, transmission corridor, Utah and Nevada, Consultant. 



\section{Publications:}

Welsh, S. L. 1957. An ecological survey of the vegetation of the $86 \mathrm{p}$.

Welsh, S. L. and E. M. Christensen. 1957. An ecological study of the vegetation of the Dinosaur National Monument. Proc. Utah Acad.
$34: 55-56$. occidentale (Leguminosae). Brittonia 12:114-118. Welsh, S. L. 1960. Legumes of the North Central states: Galegeae.
Iowa State Jour. Sci. 35:111-250. Oriental milkweed from an Iowa cornfield. Brittonia 14:186-188. Welsh, S. L. 1963. New variety and new combination in Oxytropis
campestris. Leafl. West Bot. 10:24-26.

Welsh, S. L. 1963. Legunes of Alaska: Astragalus L. Iowa State
Jour. Sc1. 37:353-388.

Welsh, S. L. 1963. Legumes of Utah I: Preliminary Report. Proc.
Utah Acad. 40:200

Christensen, E. M. and S. L. Welsh. 1963. Presettlement vegetation of the valleys of western Summit and Wasatch Counties, Utah. Proc.
Utah Acad. 40:163-174.

Welsh, S. L. and J. A. Erdman. 1964. Annotated checklist of the plants of Mesa Verde, Colorado. Brigham Young Univ. Sci. Bull.
Bio. Ser. $4(2): 1-32$.

Harrison, B. F., S. L. Welsh, and G. Moore. 1964. Plants of Arches National Monument. Brigham Young Univ. Sci. Bull. Bio. Ser. 5(1):
$1-23$.

Welsh, S. L. 1964. Legumes of Utah II: Conspectus of the Genera.

Treshow, M., S. L. Welsh, and G. Moore. 1964. Guide to the woody plants of Utah. Ed. 2. Boulder, Colorado: Pruett Press. $160 \mathrm{p}$. 

Welsh, S. L. 1966. Problems in the Alaskan Flora. Proc. Utah Acad. 43:24-27.

Welsh, S. L. 1966. Legumes of Utah III: Lathyrus L. Proc. Utah Acad. 42:214-221.

Welsh, S. L. 1967. Legumes of Alaska II: Oxytropis DC. Iowa State Jour. Sc1. 41:277-303.

Welsh, S. L. and J. L. Reveal. 1968. A new species of Townsendia from Utah. Brittonia 20:375-377.

Welsh, S. L. 1968. Nomenclature changes in the Alaskan Flora. Great Basin Nat. $28: 147-156$.

Welsh, S. L. and G. Moore. 1968. Plants of Natural Bridges National Monument. Proc. Utah Acad. 45:220-248.

Welsh, S. L. and B. W. Olsen. 1969. A living, prehistoric lumber tree. Proc. Utah Acad. 46:149-159.

Welsh, S. L. 1970. Canyonlands flora. Naturalist 21:26-37.

Welsh, S. L. 1970. New and unusual plants from Utah. Great Basin Nat. 30:16-22.

Welsh, S. L. 1970. An undescribed species of Astragalus (Leguminosae) from Utah. Rhodora 72:189-193.

Northstrom, T. E. and S. L. Welsh. 1970. Revision of the Hedysarum boreale complex. Great Basin Nat. 30:109-130.

Welsh, S. L. and J. K. Rigby. 1971. Botanical and physiographic reconnaissance of northern British Columbia. Brigham Young Univ. Sci. Bull. Bio. Ser. 14(4):1-49.

Murdock, J. R. and S. L. Welsh. 1971. Land use in Wah Wah and Pine Valleys, Western Utah. Brigham Young Univ. Sci. Bull. Bio. Ser. $12(4): 1-25$.

Welsh, S. L. and J. K. Rigby. 1971. Botanical and physiographic reconnaissance of northern Yukon. Brigham Young Univ. Sci. Bull. Bio. Ser. 12(2):1-64.

Welsh, S. L. 1971. Description of a new species of Dalea (Leguminosae) from Utah. Great Basin Nat. 31:90-92.

Rigby, J. K., W. K. Hamblin, R. Matheny, and S. L. Welsh. 1971. Guldebook to the Colorado River Park 3: Moab to Hite, Utah through Canyonlands National Part. Brigham Young Univ. Geology Studies $18(2): 1-91$. 

Welsh, S. L. 1972. On the typification of Oxytrop1s leucantha (Pallas)
Pers. Taxon 21:155-157.

Welsh, S. L. 1971. Flowers of the Canyon County. Provo, Utah: Brigham Young University Press. $53 \mathrm{p}$.

Toft, C. A. and S. L. Welsh. 1972. A revision of the Psoralea lanceolata complex (Leguminosae). Great Basin Nat. $\frac{32: 76-87}{\text { 32: }}$

Welsh, S. L. and G. Moore. 1973. Utah Plants: Tracheophyta. Provo,
Utah: Brigham Young University Press. 473 p.

Welsh, S. L. and B. Ratcliffe. 1973. Wildflowers of the Rocky Mountains. Audubon Nature Bulletin NB5. 6 p.

Rigby, J. K., L. F. Hintze, and S. L. Welsh. 1974. Geologic guide to the northwestern Colorado Plateau. Brigham Young Univ.
Geology Studies 21(2):1-117.

Welsh, S. L. and C. A. Toft. 1974. Water Stone Sky, a pictorial essay of Lake Powell. Provo, Utah: Brigham Young University Press. $77 \mathrm{p}$.

Welsh, S. L. 1974. Anderson's flora of Alaska and adjacent parts of Canada. Provo, Utah: Brigham Young University Press. 774 p.

Welsh, S. L. 1974. Utah plant novelties in Astragalus and Yucca.
Great Basin Nat. 34:305-310.

Welsh; S. L. and B. Ratcliffe. 1975. Flowers of the mountain country. Provo, Utah: Brigham Young University Press. $104 \mathrm{p}$.

Welsh, S. L., J. R. Murdock, and B. W. Wood. 1975. Environmental baseline studies of the Navajo--Kalparowits vicinity, southern Utah and northern Arizona. Great Basin Nat.: In preparation

Welsh, S. L. 1975. Utah plant novelties in Cymopterus and Penstemon.
Great Basin Nat. 35:377-378.

Welsh, S. L., N. D. Atwood, and J. L. Reveal. 1976. Endangered, threatened, extinct, endemic, and rare or restricted Utah plants.
Great Basin Nat. $35: 327-376$.

Welsh, S. L. and J. K. Rigby. 19\$5. Phytogeographic significance of the vascular flora of Northern Yukon Terrftory, Canada. Abstracts,
XII International Botanical Congress $1: 123$.

Welsh, S. L. 1976. Problems in plant endemism on the Colorado Plateau. 2ympostum on Great Basin biogeography. Mem. Great Basin Naturalist: 

Welsh, S. L. and K. H. Thorne. 1977. Plants of Arizona: A new species of Astragalus from the Kaiparowits Plateau. Great Basin Nat. 37: 103-104.

Welsh, S. L. and N. D. Atwood. 1977. An undescribed species of Thelypodiopsis (Brassicaceae) from the Uinta Basin, Utah. Great Basin Nat. 37:95-96.

Welsh, S. L. and J. L. Reveal. 1978. Utah Flora: Brassicaceae (Cruciferae). Great Basin Nat. 37:279-365.

Welsh, S. L. 1978. Endangered and threatened plants of Utah: a re-evaluation. Great Basin Nat. 38:1-18.

Welsh, S. L., N. D. Atwood and J. R. Murdock. 1978. Kaiparowits Flora. Great Basin Nat. 38:125-179.

Welsh, S. L. 1978. Utah Flora: Fabaceae (Leguminosae). Great Basin Nat. $38: 225-367$. 


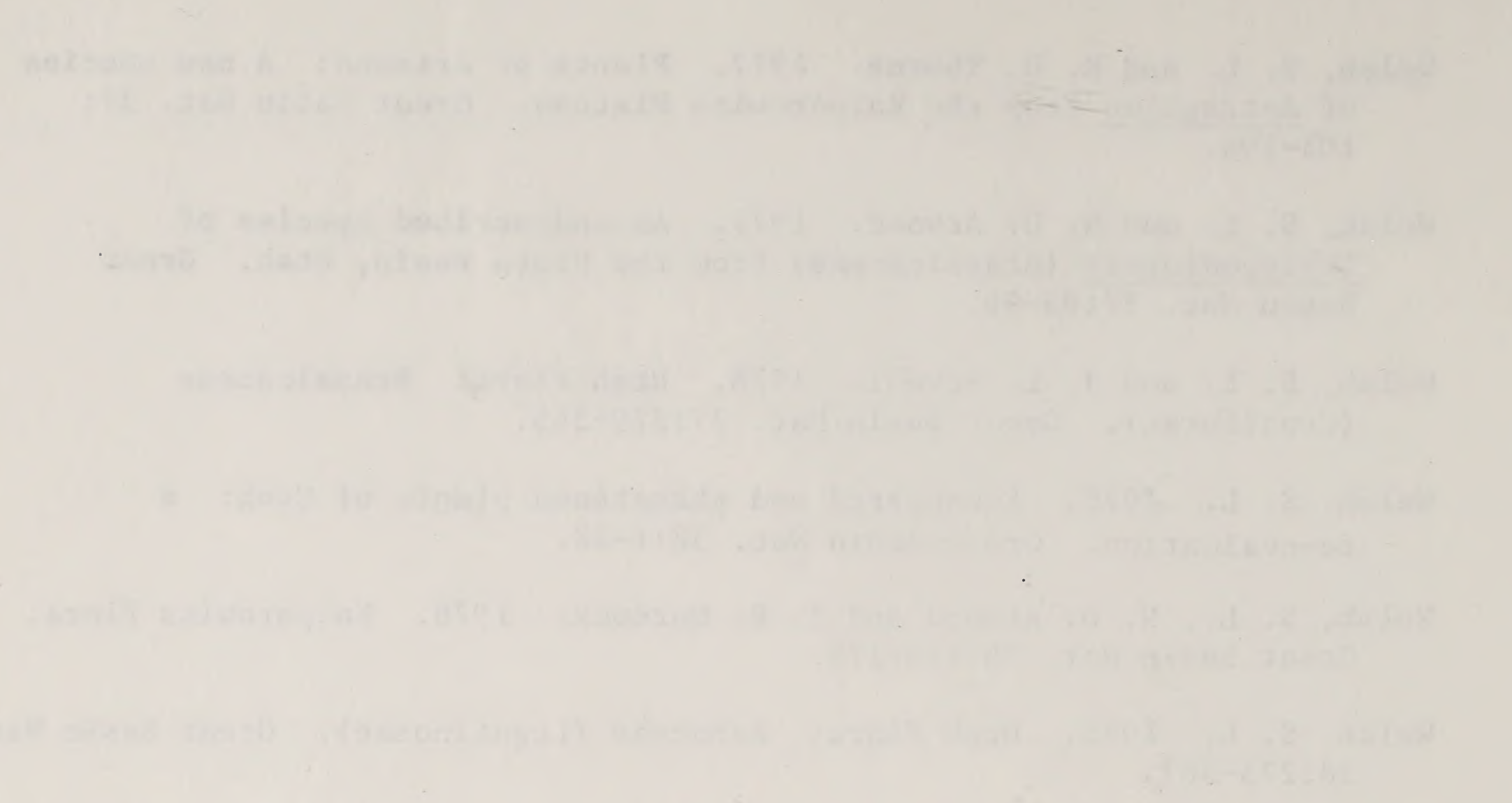




\section{CURRICULUM VITAE}

Name: Robert H. Foster

Birthdate: 4 November 1920

Birthplace: Monroe, Walton Co., Georgia

Title: Professor emeritus of Earth Science

Education:

\section{Institution and Location}

Monroe High School, Monroe, Georgia U.S. Air Corps Mechanic School Aircraft Propellar School B-29 Flight Engineer School SAC Prd Control School SAC Survival Training University of Georgia, Athens, Georgia

Brigham Young University, Provo, Utah

Brigham Young University, Provo, Utah

NSF Chataugua Clark University, Atlanta, Georgia

NSF Chataugua Clark University, Atlanta, Georgia

NSF Chataugua Clark University, Atlanta, Georgia

\begin{tabular}{|c|c|c|}
\hline Degree & $\begin{array}{c}\text { Year } \\
\text { Conferred } \\
\end{array}$ & $\begin{array}{c}\text { Scientific } \\
\text { Field }\end{array}$ \\
\hline & $\begin{array}{l}1937 \\
1940 \\
1940 \\
1945 \\
1951 \\
1953\end{array}$ & \\
\hline B.S. & 1963 & Earth Sciences \\
\hline M.S. & 1966 & Geography \\
\hline $\mathrm{Ph} . \mathrm{D}$. & $\begin{array}{c}1968 \\
1972-73\end{array}$ & $\begin{array}{l}\text { Botany } \\
\text { (Biogeography) } \\
\text { Energy Resources }\end{array}$ \\
\hline & $\begin{array}{l}1973-74 \\
1974-75\end{array}$ & $\begin{array}{l}\text { Atmospheric } \\
\text { electricity } \\
\text { Atmospheric } \\
\text { pollution }\end{array}$ \\
\hline
\end{tabular}

Honors: NDEA Fellowship, Brigham Young University, Provo, Utah 1966-1968. Phi Kappa Phi, Brigham Young University, Provo, Utah 1966. Society of the Sigma Chi President, Western Kentucky University Chapter 1971-1972.

Major Research Interests: General distribution of plants in Utah The extent of naturalization of Tamarix in the U.S. southwest 

Research and Professional Experience:

1939 - 1960, United States Air Force, afrcraft maintenance-engineering, Flight engineer.

May - Sept. 1951, U.S. Forest Service, Pinedale, Wyoming, Bark-beetle conirol, Engelman spruce.

May - Sept. 1962, U.S. Forest Service, Pinedale, Wyoming, Bark-beetle control, Engelman spruce.

May - Sept. 1963, U.S. Forest Service, Mt. View, Wyoming, Bark-beetle control, Engelnan spruce.

1963 - 1964, University of Georgia, Instructor in Physical Geography.

May - August 1967, Utah Conservation Dept. Survey of wetland plants.

1968 - 1976, Professor of Earth Sciences, Western Kentucky University, Bowling Green, Kentucky.

May - August 1970 - 1972, Field study distribution of Tamarix in U.S. southwest.

May - August 1971, Field study on disjunct stands of hemlock in Kentucky.

May - August 1974, Director of 100 member youth conservation corp camp, Bowling Green, Kentucky.

May - August 1975, Director of 100 member youth conservation corp camp, Bowling Green, Kentucky.

Dec. 1976 - Feb. 1977, Field study plants of southern Arizona.

April - Nov. 1977, US Geological Survey, threatened and endangered species of the Southern and Central Coal lands; Utah.

Publications and Manuscripts:

Foster, R. F. 1965. Distribution of Major Plant Communities in the Great Basin area of Utah. M.S. Thesis. $78 \mathrm{pp}$.

- 1968. Distribution of Major Plant Communities in Utah. Ph.D. Thesis. $124 \mathrm{pp}$.

- 1974. Map of Plant Communities of Utah - Utah Atlas of Natural Resources.

1974. Upper extent of Tamarix in U.S. Southwest. Kentucky Acad. Sci. 21 .

1978. Life History and Community study of Tamarix ramosissima. In preparation. 



\section{CURRICULUM VITAE}

Name: Dan A. Foster

Birthdate: 4 February 1956

Birthplace: Valparaiso, Okaloosa, Florida

Title: Junior Investigator

Education:

Institution and Location Year $\underline{\underline{\text { Field }}}$

Bowling Green High School, Bowling Green, Ky. 1973

Western Kentucky University, Bowling Green, Ky. 1974 - Spring Botony/Geology

Brigham Young Universtiy, Provo, Utah

1974 - Fall

1977 - 1979

Honors: Outstanding 1st year cadet ROTC, Western Kentucky University

Research Interest:

Relationship between geological formations and plant distribution.

Research and Professional Experience:

June - Sept. 1971 Student asst. on Field study on disjunct stands of hemlock in Kentucky.

June - Sept. 1970 - 1972, Student asst. on Field study distribution of Tamarax in U.S. southwest.

Aug. 1972 - June 1974 Leichhardt Nursery, Bowling Green, Ky.

June - Sept 1974 Asst. crew leader, U.S. Youth Conservation Corps, Bowling Green, Ky. (Development of city arboretum and parks)

Apr. 1975 - Apr. 1977 Missionary The Church of Jesus Christ of Latter-day Saints Vancouver Canada Mission.

May - Sept. 1977 Junior Investigator, Threatened and Endangered plants Survey of the Southern and Central Coal lands, Utah.

Apr. - Oct. 1978 Landscape specialist, Provo, Utah - Las Vegas, Nevada. 


